\title{
Pengaruh suplementasi Zn terhadap perubahan indeks TB/U anak stunted usia 24-36 bulan
}

\author{
Dewi Pertiwi Dyah Kusudaryati ${ }^{1}$, Siti Fatimah Muis $^{2}$, Laksmi Widajanti ${ }^{3}$
}

\begin{abstract}
Background : Zn supplementation on stunted children in multiple research get the result inconsistent concerning the effect of Zn on children's growth.

Objective : To examine the effect of Zn supplementation to the change in height for index among stunted children age between 24-36 months.

Methods: The research design is randomized pretest posttest control group design. The total of thirty six stunted children are divided into two groups. The treatment group is received syrup with $20 \mathrm{mg} \mathrm{ZnSO}_{4}$ twice a week for three months. The control group received placebo without Zn. Height for age z score (HAZ) on WHO Child Growth 2006 is used to measure height for age index while dietary intake and infection diseases are used as confounding variables.

Result : There is significant difference in HAZ before and after supplementation at treatment group (p<0.001) and control group ( $p<0.001)$. There is a significant difference of the change in HAZ between the treatment group and control group ( $p=0.006)$. Percentage Achievement of Energy, Protein, and Zn Dietary Allowance have significant difference between the treatment group and control group ( $p=0.009 ; p<0.001 ; p<0.001$, respectively). The change in HAZ, Percentage Achievement of Energy, Protein, and $\mathrm{Zn}$ Dietary Allowance are higher in treatment group than control group. Duration of diarrhea $(p=0.045)$ and morbidity $(p=0.019)$ are lower in treatment group than control group.

Conclusion : Zn Supplementation among stunted children have significant effect on the change in HAZ, dietary intake, and infection.
\end{abstract}

Keywords : Zn supplementation, stunted children, HAZ.

\section{ABSTRAK}

Latar Belakang : Suplementasi Zn pada anak stunted di beberapa penelitian mendapatkan hasil yang masih tidak konsisten tentang pengaruh Zn terhadap pertumbuhan anak.

Tujuan : Mengetahui pengaruh suplementasi Zn terhadap perubahan skor Z TB/U pada anak stunted usia 24-36 bulan.

Metode : Eksperimen dengan rancangan tes awal tes akhir kelompok kontrol dengan sampel acak. Sebanyak 36 anak stunted

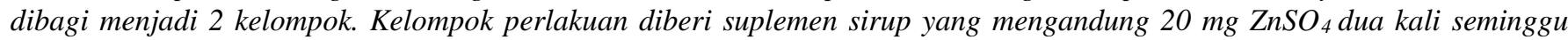
selama 3 bulan sedangkan kelompok pembanding diberi sirup plasebo tanpa Zn. Indeks TB/U yang digunakan adalah skor Z TB/U berdasarkan WHO Child Growth 2006 sedangkan asupan gizi dan penyakit infeksi digunakan sebagai variabel perancu.

Hasil Penelitian : Skor Z TB/U berbeda bermakna sebelum dan setelah suplementasi pada kelompok perlakuan (p<0,001) dan kelompok pembanding ( $p<0,001)$. Perubahan skor Z TB/U kelompok perlakuan lebih tinggi dan berbeda bermakna dibanding kelompok pembanding $(p=0,006)$. Asupan energi, protein, dan Zn kelompok perlakuan lebih tinggi dibanding kelompok pembanding $(p=0,009, p<0,001, p<0,001$, berturut-turut $)$. Lama diare $(p=0,045)$ dan morbiditas $(p=0,019)$ kelompok perlakuan lebih rendah bermakna dibanding kelompok pembanding.

Simpulan : Suplementasi Zn pada anak stunted berpengaruh terhadap perubahan skor ZTB/U, asupan gizi dan kejadian infeksi.

Kata kunci : suplementasi Zn, anak stunted, skor Z TB/U.

\section{PENDAHULUAN}

Pertumbuhan anak dipengaruhi oleh dua faktor, yaitu faktor langsung dan faktor tidak langsung. Faktor langsung yang mempengaruhi pertumbuhan anak diantaranya asupan gizi, penyakit infeksi, dan genetik. Sedangkan faktor tidak langsung meliputi akses pelayanan kesehatan, sosial ekonomi (pendapatan

\footnotetext{
1. Prodi Gizi, STIKES PKU Muhammadiyah Surakarta (email korespondensi : de_tiwi11@yahoo.co.id)

2. Bagian Gizi, Fakultas Kedokteran Universitas Diponegoro, Semarang

3. Fakultas Kesehatan Masyarakat Universitas Diponegoro, Semarang
}

keluarga), pengetahuan dan pendidikan ibu, serta persediaan makanan di rumah. ${ }^{1}$

Salah satu dampak jika seorang anak kekurangan gizi yaitu terjadinya penurunan kecepatan pertumbuhan atau gangguan pertumbuhan linear sehingga anak gagal dalam mencapai potensi tinggi badan yang mengakibatkan anak stunted (pendek) (Siregar, 2011). ${ }^{2}$ Selain kekurangan gizi kronik, penyebab anak stunted adalah penyakit infeksi yang dapat memperburuk status gizi ${ }^{1}$ dan jika berlangsung terus menerus akan menghambat pertumbuhan fisik anak. $^{2}$

Prevalensi balita stunted secara nasional tahun 2010 sebesar 35,6 \%. Prevalensi balita dan batita usia 24 - 35 bulan dengan kategori sangat pendek di Jawa 
Tengah adalah $16.9 \%$ dan $22.8 \%$, sedangkan yang masuk kategori pendek adalah $17.0 \%$ dan $18.6 \%$. Prevalensi batita sangat pendek usia 24-35 mengalami peningkatan dibandingkan hasil Riskesdas tahun 2007 yaitu $21.5 \%$ menjadi $22.8 \%$. $^{3}$ Di Kota Surakarta prevalensi balita sangat pendek dan pendek sebesar $12.3 \%$ dan $10.3 \%{ }^{4}$

$\mathrm{Zn}$ adalah zat gizi yang berperan penting pada banyak fungsi tubuh seperti pertumbuhan sel, pembelahan sel, metabolisme tubuh, fungsi imunitas dan perkembangan. ${ }^{5,6}$ Suplementasi $\mathrm{Zn}$ secara bermakna mempunyai respon yang positif terhadap kenaikan berat badan dan tinggi badan, serta mampu meningkatkan pertumbuhan linear pada remaja dan anak stunted..$^{5}$

Penelitian dengan skala kecil yang dilakukan di Jawa Tengah, Jawa Barat, Lombok, dan NTB antara tahun 1997-1999 menemukan defisiensi Zn pada bayi berkisar antara $6 \%-39 \% .^{7}$ Penelitian pada bayi di Bogor Jawa Barat mendapatkan prevalensi defisiensi Zn mencapai $17 \%{ }^{8}$ dan di Indramayu $47,9 \%{ }^{9}$ Sedangkan penelitian di Grobogan Jawa Tengah dan NTT pada 500 anak usia sekolah yang mengalami defisiensi $\mathrm{Zn}$ masing-masing sebesar $26,8 \%$ dan $24,2 \% .{ }^{10}$ Survei pada 9 propinsi menemukan prevalensi defisiensi $\mathrm{Zn}$ pada balita rata-rata $31,9 \%$ dengan kisaran 11,7\% (Sumatera Barat) sampai 46,6\% (NTB). ${ }^{11}$

Pentingnya $\mathrm{Zn}$ untuk pertumbuhan linear anak terutama yang masih dalam masa pertumbuhan menjadi dasar peneliti melakukan penelitian untuk mengetahui apakah ada pengaruh suplementasi $\mathrm{Zn}$ terhadap perubahan indeks antropometri TB/U pada anak stunted usia 24-36 bulan.

\section{BAHAN DAN METODE}

Penelitian dilaksanakan di beberapa tempat PAUD (Pendidikan Anak Usia Dini) yaitu Kelompok Bermain (KB), Pos PAUD dan Tempat Penitipan Anak (TPA) wilayah kecamatan Pasar Kliwon Kota Surakarta, Jawa Tengah. Penelitian dilaksanakan pada bulan Maret-Juni 2012. Desain penelitian yang digunakan adalah desain eksperimen dengan randomized pretest posttest control group design.

Subyek dalam penelitian ini adalah anak usia 2436 bulan yang diperoleh melalui PAUD dan diambil dengan metode simple random sampling yang memenuhi kriteria: bertempat tinggal di wilayah kecamatan Pasar Kliwon Surakarta, usia 24-36 bulan, skor $\mathrm{Z} \mathrm{TB} / \mathrm{U}<-2 \mathrm{SB}$, tidak menderita penyakit kronis dan cacat bawaan, orang tuanya (ibu) bersedia menjadi responden dan anaknya menjadi subyek penelitian. Jumlah subyek sebanyak 36 anak, dibagi menjadi dua kelompok yaitu 18 anak pada kelompok perlakuan dan 18 anak pada kelompok kontrol. Tinggi badan subyek diukur menggunakan mikrotoa dan umur diperoleh dari data tanggal lahir pada buku induk di PAUD. Skor Z TB/U dihitung dengan software WHO Anthro 2005.

Kelompok perlakuan diberi suplemen sirup $\mathrm{ZnSO}_{4}$ (Zinc Sulfate) dengan dosis $20 \mathrm{mg}$ diberikan $2 \mathrm{x} /$ minggu selama 12 minggu (3 bulan). Suplemen sirup $\mathrm{ZnSO}_{4}$ (Zinc Sulfate) dibeli di bagian Farmasi Fakultas Kedokteran Universitas Diponegoro Semarang. Kelompok kontrol diberi sirup plasebo tanpa $\mathrm{Zn}$. Asupan energi, protein, dan $\mathrm{Zn}$ dikumpulkan setiap 1 bulan menggunakan metode food recall 2 x 24 jam tidak berturut-turut kemudian dibandingkan dengan Angka Kecukupan Gizi (AKG) tahun 2012. Penyakit infeksi (diare, batuk, pilek, dan demam) diperoleh dengan cara wawancara menggunakan kuesioner yang dilakukan setiap 2 minggu sekali terhitung sejak dimulainya penelitian.

Analisis data dilakukan dengan Independent $t$ test dan Paired t test untuk data yang berdistribusi normal, Mann Whitney dan Wilcoxon test untuk data berdistribusi tidak normal serta Chi Square untuk data kategori. Analisis multivariat regresi linier berganda digunakan untuk menguji pengaruh bersama-sama variabel perancu (asupan gizi dan penyakit infeksi) terhadap variabel terikat perubahan skor Z TB/U. Semua kegiatan dari pengumpulan hingga analisis data dilakukan sendiri oleh peneliti.

\section{HASIL}

\section{Karakteristik Subyek dan Responden}

Karakteristik awal subyek meliputi jenis kelamin dan usia, sedangkan karakteristik ibu adalah pendidikan seperti yang ditunjukkan pada Tabel 1 .

Pada awal penelitian jenis kelamin, usia, tinggi badan, skor Z TB/U, tingkat kecukupan energi (TKE), tingkat kecukupan protein (TKP), dan tingkat kecukupan Zn (TKZn) subyek dan pendidikan ibu tidak ada perbedaan $(p>0,05)$ antara kelompok perlakuan dengan kelompok pembanding (Tabel 1).

Setelah 3 bulan suplementasi, diketahui bahwa tidak ada perbedaan $\mathrm{TB}$ dan skor $\mathrm{Z} \mathrm{TB} / \mathrm{U}$ antara kelompok perlakuan dengan kelompok pembanding, namun TKE, TKP, dan TKZn di akhir penelitian menunjukkan perbedaan diantara kedua kelompok. Rerata TKE, TKP, dan TKZn lebih tinggi pada kelompok perlakuan dibanding kelompok pembanding (Tabel 2). 
Tabel 1. Gambaran umum subyek dan responden pada awal penelitian antara kelompok perlakuan dan pembanding

\begin{tabular}{lcccc}
\hline \multicolumn{1}{c}{ Variabel } & $\begin{array}{c}\text { Perlakuan } \\
\mathbf{n = 1 8}\end{array}$ & $\begin{array}{c}\text { Pembanding } \\
\mathbf{n}=\mathbf{1 8}\end{array}$ & Nilai & $\boldsymbol{p}$ \\
\hline $\begin{array}{l}\text { Subyek } \\
\text { Jenis Kelamin }\end{array}$ & & & & \\
- Laki-laki & $7(38,9 \%)$ & $7(38,9 \%)$ & $\mathrm{x}^{2}<0,001^{\mathrm{a}}$ & 1,000 \\
- Perempuaan & $11(61,1 \%)$ & $11(61,1 \%)$ & & \\
Usia (bulan) & $31,3( \pm 3,61)$ & $31,2( \pm 3,43)$ & $\mathrm{t}=0,047^{\mathrm{b}}$ & 0,963 \\
TB (cm) & $83,0( \pm 2,80)$ & $83,8( \pm 2,32)$ & $\mathrm{t}=-0,926^{\mathrm{b}}$ & 0,361 \\
Skor Z TB/U (SB) & $-2,7( \pm 0,62)$ & $-2,4( \pm 0,24)$ & $\mathrm{z}=-0,443^{\mathrm{c}}$ & 0,658 \\
TKE (\%) & $80,8( \pm 17,3)$ & $79,3( \pm 11,17)$ & $\mathrm{z}=-0,237^{\mathrm{c}}$ & 0,812 \\
TKP (\%) & $85,4( \pm 21,6)$ & $81,4( \pm 12,4)$ & $\mathrm{t}=0,684^{\mathrm{b}}$ & 0,500 \\
TKZn (\%) & $61,4( \pm 2,95)$ & $57,2( \pm 8,58)$ & $\mathrm{z}=-0,776^{\mathrm{c}}$ & 0,438 \\
Responden & & & & \\
Pendidikan Ibu (tahun) & $10,9( \pm 2,99)$ & $9,8( \pm 3,49)$ & $\mathrm{t}=1,338^{\mathrm{b}}$ & 0,190 \\
\hline
\end{tabular}

${ }^{\mathrm{a}}$ Uji Chi Square; ${ }^{\mathrm{b}}$ Independent t test; ${ }^{\mathrm{c}}$ Uji Mann Whitney

Tabel 2. Gambaran umum subyek pada akhir penelitian antara kelompok perlakuan dan pembanding

\begin{tabular}{|c|c|c|c|c|}
\hline Variabel & $\begin{array}{c}\text { Perlakuan }(\mathbf{n}=18) \\
\bar{x} \pm S B\end{array}$ & $\begin{array}{c}\text { Pembanding }(\mathbf{n}=18) \\
\bar{x} \pm S B\end{array}$ & Nilai & $p$ \\
\hline TB $(\mathrm{cm})$ & $85,4( \pm 2,73)$ & $85,8( \pm 2,19)$ & $\mathrm{t}=-0,511^{\mathrm{a}}$ & 0,613 \\
\hline Skor Z TB/U (SB) & $-2,5( \pm 0,59)$ & $-2,3( \pm 0,26)$ & $z=-0,079^{b}$ & 0,937 \\
\hline TKE (\%) & $91,3( \pm 11,6)$ & $81,2( \pm 10,0)$ & $\mathrm{t}=2,766^{\mathrm{a}}$ & $0,009^{*}$ \\
\hline $\operatorname{TKP}(\%)$ & $104,0( \pm 11,8)$ & $80,9( \pm 13,6)$ & $\mathrm{t}=5,422^{\mathrm{a}}$ & $<0,001^{*}$ \\
\hline TKZn $(\%)$ & $88,0( \pm 4,8)$ & $60,5( \pm 10,5)$ & $\mathrm{t}=10,038^{\mathrm{a}}$ & $<0,001^{*}$ \\
\hline
\end{tabular}

${ }^{*} p<0,05,{ }^{\mathrm{a}}$ Independent $t$ test $;{ }^{\mathrm{b}}$ Uji Mann Whitney

Tabel 3. Uji beda TB, skor Z TB/U, TKE, TKP, dan TKZn pada kelompok perlakuan dan pembanding sebelum dan setelah suplementasi

\begin{tabular}{lcccc}
\hline \multirow{2}{*}{ Variabel } & \multicolumn{2}{c}{ Perlakuan $(\mathbf{n = 1 8})$} & \multicolumn{2}{c}{ Pembanding $(\mathbf{n}=\mathbf{1 8})$} \\
\cline { 2 - 5 } & \multicolumn{1}{c}{ Nilai } & $\boldsymbol{p}$ & Nilai & $\boldsymbol{p}$ \\
\hline TB & $\mathrm{t}=-37,176^{\mathrm{a}}$ & $<0,001^{*}$ & $\mathrm{t}=-29,992^{\mathrm{a}}$ & $<0,001^{*}$ \\
Skor Z TB/U & $\mathrm{z}=-3,726^{\mathrm{b}}$ & $<0,001^{*}$ & $\mathrm{t}=-5,560^{\mathrm{a}}$ & $<0,001^{*}$ \\
TKE & $\mathrm{t}=-3,995^{\mathrm{a}}$ & $0,001^{*}$ & $\mathrm{z}=-1,285^{\mathrm{b}}$ & 0,199 \\
TKP & $\mathrm{t}=-5,123^{\mathrm{a}}$ & $<0,001^{*}$ & $\mathrm{t}=0,227^{\mathrm{a}}$ & 0,823 \\
TKZn & $\mathrm{t}=-3,724^{\mathrm{a}}$ & $<0,001^{*}$ & $\mathrm{z}=-1,894^{\mathrm{b}}$ & 0,058 \\
\hline${ }^{*} p<0,05,{ }^{a}$ Paired t test ${ }^{b}{ }^{\mathrm{b}}$ Uji Wilcoxon & & &
\end{tabular}

Tabel 4. Beda rerata perubahan TB, skor $Z$ TB/U, TKE, TKP, dan TKZn antara kelompok perlakuan dan pembanding

\begin{tabular}{lcccc}
\hline \multicolumn{1}{c}{ Variabel } & Perlakuan $(\mathbf{n}=\mathbf{1 8})$ & Pembanding $(\mathbf{n}=\mathbf{1 8})$ & \multirow{2}{*}{$\mathbf{t}^{* *}$} & $\boldsymbol{p}^{*}$ \\
\hline$\Delta \mathrm{TB}(\mathrm{cm})$ & $2,4( \pm 0,27)$ & $2,0( \pm 0,29)$ & 3,992 & $<0,001$ \\
$\Delta$ Skor Z TB/U (SB) & $0,2( \pm 0,07)$ & $0,1( \pm 0,08)$ & 2,994 & 0,006 \\
$\Delta \mathrm{TKE}(\%)$ & $10,5( \pm 11,2)$ & $1,9( \pm 7,7)$ & 2,668 & 0,012 \\
$\Delta \mathrm{TKP}(\%)$ & $18,6( \pm 15,4)$ & $-0,4( \pm 7,4)$ & 4,720 & $<0,001$ \\
$\Delta \mathrm{TKZn}(\%)$ & $26,6( \pm 3,9)$ & $3,3( \pm 6,3)$ & 13,295 & $<0,001$ \\
\hline${ }^{*} p<0,05,{ }^{* *}$ Independent t test & & & &
\end{tabular}

Uji perbedaan yang dilakukan pada kelompok perlakuan menunjukkan hasil bahwa TB, skor Z TB/U, TKE, TKP, dan TKZn berbeda sebelum dan setelah suplementasi $(\mathrm{p}<0,05)$. TB dan skor $\mathrm{Z} \mathrm{TB} / \mathrm{U}$ berbeda tetapi TKE, TKP, dan TKZn tidak berbeda sebelum dan 
setelah intervensi pada kelompok pembanding (Tabel $3)$.

Tabel 4 menunjukkan bahwa rerata perubahan TB, skor Z TB/U, TKE, TKP, dan TKZn berbeda bermakna antara kelompok perlakuan dengan pembanding. Rerata perubahan TB, skor Z TB/U, TKE, TKP, dan TKZn lebih tinggi pada kelompok perlakuan dibanding kelompok pembanding.

Tabel 5. Beda rerata frekuensi dan lama diare serta batuk, pilek dan demam antara kelompok perlakuan dan pembanding

\begin{tabular}{lcccc}
\hline \multicolumn{1}{c}{ Variabel } & Perlakuan $(\mathbf{n}=\mathbf{1 8})$ & Pembanding $(\mathbf{n}=\mathbf{1 8})$ & $\mathbf{z}^{* * *}$ & $\boldsymbol{p}$ \\
\hline Diare & & $\overline{\mathbf{x}} \pm \mathbf{S B}$ & & \\
$\quad$ Frekuensi (kali) & $0,4( \pm 0,62)$ & $0,9( \pm 0,80)$ & $-1,946$ & 0,052 \\
$\quad$ Lama (hari) & $0,9( \pm 1,23)$ & $2,2( \pm 1,98)$ & $-2,002$ & $0,045^{*}$ \\
Batuk, Pilek, Demam & & & & \\
$\quad$ Frekuensi (kali) & $0,7( \pm 0,84)$ & $1,8( \pm 1,39)$ & $-2,492$ & $0,013^{*}$ \\
Lama (hari) & $1,7( \pm 2,42)$ & $4,6( \pm 3,76)$ & $-2,353$ & $0,019^{*}$ \\
\hline${ }^{*} p<0,05,{ }^{* *}$ Uji Mann Whitney & & & &
\end{tabular}

Tabel 5 menunjukkan bahwa rerata lama diare, frekuensi dan lama batuk, pilek dan demam berbeda bermakna antara kelompok perlakuan dengan pembanding tetapi frekuensi diare tidak berbeda antara kedua kelompok tersebut ( $p>0,05)$. Rerata lama diare, frekuensi dan lama batuk, pilek dan demam pada kelompok perlakuan lebih rendah (singkat) daripada kelompok pembanding selama penelitian.

Tabel 6. Pengaruh variabel-variabel perancu terhadap

\begin{tabular}{lcc}
\hline \multicolumn{1}{c}{ Variabel } & B & $\mathbf{p}^{* *}$ \\
\hline TKE $(\%)$ & 0,000 & 0,610 \\
TKP $(\%)$ & 0,000 & 0,823 \\
TKZn $(\%)$ & 0,002 & $0,042^{*}$ \\
Lama Diare (hari) & $-0,003$ & 0,750 \\
Lama batuk, pilek, demam (hari) & 0,014 & 0,288 \\
Frek. batuk, pilek, demam (kali) & $-0,056$ & 0,119 \\
${ }^{*} p<0,05,{ }^{* *}$ Uji Regresi Linier Berganda & &
\end{tabular}

Uji multivariat menggunakan regresi linier berganda mendapatkan nilai Adjusted $R$ Square $=0,232$ yang artinya secara bersama-sama tingkat kecukupan energi, protein, $\mathrm{Zn}$, lama diare, serta lama dan frekuensi batuk, pilek, dan demam berpengaruh terhadap perubahan skor Z TB/U sebesar 23,2\%. Analisis lebih lanjut menyimpulkan bahwa hanya tingkat kecukupan $\mathrm{Zn}$ yang berpengaruh signifikan terhadap perubahan skor Z TB/U (p = 0,042) (Tabel 6).

\section{PEMBAHASAN}

Karakteristik subyek dan responden pada awal penelitian tidak ada perbedaan antara kelompok perlakuan dan pembanding. Pada penelitian eksperimental harus memiliki kesetaraan karakteristik sehingga distribusi subyek dan responden tersebar secara merata.

Adanya perbedaan Skor Z TB/U antara kelompok perlakuan dengan kelompok pembanding setelah suplementasi $\mathrm{Zn}$ menunjukkan kesamaan dengan metaanalisis yang dilakukan oleh Brown et al bahwa suplementasi $\mathrm{Zn}$ mempunyai dampak positif pada pertumbuhan linier anak. ${ }^{12}$ Adanya pengaruh $\mathrm{Zn}$ terhadap pertumbuhan dikarenakan $\mathrm{Zn}$ termasuk salah satu zat gizi yang tergolong dalam nutrien tipe 2 . Nutrien tipe 2 merupakan bahan pokok komposisi sel dan sangat penting untuk fungsi dasar jaringan. ${ }^{13}$ Selain itu, nutrien yang masuk dalam tipe ini seperti halnya $\mathrm{Zn}$ memiliki karakteristik yaitu tidak memiliki tempat penyimpanan sehingga diperlukan masukan terusmenerus dalam jumlah yang kecil. Dampak utama jika terjadi defisiensi $\mathrm{Zn}$ adalah kegagalan pertumbuhan dan berkurangnya volume jaringan (loss of tissue). Zinc dibutuhkan untuk proses pertumbuhan bukan hanya karena efek replikasi sel dan metabolisme asam nukleat tetapi juga sebagai mediator hormon pertumbuhan. ${ }^{14}$

Pemberian suplemen $\mathrm{Zn}$ dapat meningkatkan konsentrasi plasma Insulin-like Growth Factor I (IGF I) sehingga memicu kecepatan pertumbuhan. ${ }^{15}$ Insulinlike Growth Factor I merupakan mediator hormon pertumbuhan yang berperan sebagai suatu growth promoting factor dalam proses pertumbuhan. Defisiensi hormon pertumbuhan menyebabkan 
konsentrasi IGF-I dalan sirkulasi rendah, sebaliknya hormon pertumbuhan tinggi maka konsentrasi IGF-I juga akan meningkat. ${ }^{16}$ Kegagalan pertumbuhan secara bersama-sama dijumpai dengan penurunan konsentrasi IGF-I. Menurunnya konsentrasi IGF-I disebabkan bukan hanya karena kekurangan energi protein tetapi juga kekurangan $\mathrm{Zn} .^{15}$

Pengaruh Zn terhadap perubahan skor Z TB/U (Tabel 4) juga dapat disebabkan oleh tingkat kecukupan Zn yang tergolong kurang/defisiensi serta status gizi anak yang mengalami stunted. Hal ini sesuai dengan pendapat yang dikemukakan Thu et al yang menyebutkan bahwa suplementasi mikronutrien termasuk $\mathrm{Zn}$ tidak berpengaruh terhadap indeks TB/U kecuali pada anak dengan skor $\mathrm{Z} \mathrm{TB/U}$ di bawah ratarata $(<-2$ SB) atau mengalami defisiensi Zn. Anak dengan kadar $\mathrm{Zn}$ rendah akan mengabsorbsi $\mathrm{Zn}$ lebih efisien dibandingkan dengan kadar Zn tinggi. ${ }^{17}$

Di sisi lain, hasil penelitian ini menunjukkan perbedaan dengan hasil penelitian yang dilakukan di Burkina Faso dan North India yang menyimpulkan bahwa tidak ada pengaruh suplementasi $\mathrm{Zn}$ terhadap pertumbuhan anak. ${ }^{18,19}$ Perbedaan kesimpulan tersebut karena perbedaan pada beberapa hal seperti dosis, jenis suplemen yang diberikan, dan lama pemberian suplemen. Selain itu, kedua penelitian tersebut dilakukan pada subyek dengan status gizi tidak semua anak stunted. Menurut Thu et al, suplementasi Zn akan berpengaruh terhadap anak dengan skor Z TB/U $<-2$ SB atau stunted. ${ }^{17}$

Rerata TKZn sebelum suplementasi pada kelompok perlakuan maupun pembanding sama-sama tergolong kurang (<65\% AKG). Namun setelah suplementasi, rerata TKZn pada kelompok perlakuan tergolong cukup sedangkan kelompok pembanding tetap tergolong kurang. Tingkat kecukupan $\mathrm{Zn}$ yang rendah pada semua subyek di awal penelitian ini sesuai dengan beberapa penelitian yang pernah dilakukan yang menemukan banyak data balita Indonesia mengalami defisiensi Zn. ${ }^{8,10,11}$ Defisiensi Zn cukup tinggi diperkirakan karena pola makan masyarakat Indonesia yang umumnya rendah protein hewani dan relatif tinggi fitat dan serat yang menghambat absorbsi $\mathrm{Zn} .{ }^{20}$ Keseimbangan (homeostatis) $\mathrm{Zn}$ dalam tubuh tergantung pada absorbsi dan ekskresi. Pada keadaan defisiensi $\mathrm{Zn}$, ekskresi $\mathrm{Zn}$ akan menurun sehingga kebutuhan tubuh akan $\mathrm{Zn}$ tergantung dari pengaturan makanan yang cukup agar dapat menyediakan $\mathrm{Zn}$ untuk keperluan berbagai proses metabolisme dalam tubuh. ${ }^{14}$

Setelah suplementasi Zn, TKE, TKP, dan TKZn pada kelompok perlakuan mengalami peningkatan. Hal ini disebabkan $\mathrm{Zn}$ dapat menstimulasi asupan makanan, kemungkinan melalui jalur hormonal atau neuroendocrine transmitter yang mempengaruhi selera makan sehingga dapat meningkatkan asupan makanan. ${ }^{21}$ Golden menyatakan bahwa berdasarkan penelitian Krebs et al ditemukan adanya penurunan asupan protein pada subyek yang diberi suplementasi protein saja. Sedangkan jika seseorang yang mengalami defisiensi $\mathrm{Zn}$ diberi suplemen $\mathrm{Zn}$ maka nafsu makannya akan meningkat sehingga dapat meningkatkan asupan energi, protein, dan zat gizi lain yang berhubungan dengan $\mathrm{Zn} .^{22}$

Di sisi lain, tingkat kecukupan energi, protein, dan $\mathrm{Zn}$ pada kelompok pembanding relatif sama atau tidak ada perbedaan dengan sebelum suplementasi. Asupan $\mathrm{Zn}$ tergolong kurang sehingga kemungkinan terjadi defisiensi $\mathrm{Zn}$ pada subyek di kelompok pembanding. Rendahnya asupan $\mathrm{Zn}$ yang bersumber dari makanan menyebabkan penurunan selera makan terutama berkaitan dengan gangguan pada rasa. Gangguan rasa terjadi karena konsentrasi $\mathrm{Zn}$ pada saliva (enzim $\alpha$-Amylase) yang rendah menyebabkan penurunan cita rasa yang berpengaruh pada penurunan selera makan ${ }^{21}$ sehingga akan berpengaruh pula pada tingkat kecukupan energi dan protein yang rendah.

Suplementasi $\mathrm{Zn}$ selama 3 bulan memperlihatkan pengaruh terhadap kejadian infeksi. Rerata lama dan frekuensi diare, batuk, pilek, dan demam pada kelompok perlakuan lebih singkat daripada kelompok pembanding (Tabel 5). Hal ini disebabkaan karena $\mathrm{Zn}$ berperan penting dalam sistem kekebalan (imunitas) dan merupakan mediator potensial pertahanan tubuh terhadap infeksi. ${ }^{14}$ Zinc dibutuhkan dalam imunitas spesifik untuk proliferasi limfosit sebagai respon terhadap interleukin-1 (IL-1) dan interleukin-2 (IL-2). Perkembangan limfosit B juga dipengaruhi oleh $\mathrm{Zn}$. Defisiensi $\mathrm{Zn}$ menghalangi perkembangan limfosit $B$ di sumsum tulang serta menurunkan jumlah limfosit B di lien. Zinc dibutuhkan untuk mitogenik limfosit $\mathrm{B}$ dan respon sitokin terhadap lipopolisakaridase. Di samping itu, Zn juga dibutuhkan untuk sistem imunitas non spesifik. Zinc dapat meningkatkan aktifitas sel natural killer (NK) dan menstimulasi produksi interferon $\gamma$ oleh sel NK darah perifer. $^{6}$

Pengaruh suplemen Zn terhadap kejadian diare sesuai dengan penelitian Bhutta bahwa suplementasi $\mathrm{Zn}$ dapat mengurangi lama dan beratnya kejadian diare. ${ }^{23}$ Pada keadaan diare, $\mathrm{Zn}$ berperan sebagai antioksidan, mempengaruhi absorpsi air dan natrium, meningkatkan metabolisme vitamin A, mencegah defisiensi enzim disakaridase, meningkatkan sistem imun, dan sebagai ko-faktor enzim. ${ }^{24}$ Suplementasi $\mathrm{Zn}$ dapat menurunkan kejadian anoreksia dan kesakitan seperti batuk, demam, pilek, dan rasa mual pada anak stunted. . $^{25}$

Infeksi berkaitan dengan pertumbuhan anak. Penyakit infeksi dan pertumbuhan sering terjadi bersama-sama dan keduanya dapat saling mempengaruhi. Infeksi dapat disebabkan dan 
menyebabkan kekurangan gizi. Sebaliknya kekurangan gizi dapat menurunkan daya tahan tubuh dari serangan infeksi. Penyakit infeksi yang diderita anak menyebabkan absorbsi dan nafsu makan menurun sehingga asupan makanan berkurang serta kurangnya kemampuan anak menerima makanan sementara kebutuhan tubuh semakin meningkat. Hal ini yang mengakibatkan gangguan pertumbuhan dengan ciriciri terhambat atau terhentinya pertumbuhan linear. ${ }^{1,26}$

Hasil analisis regresi linier menunjukan bahwa selain suplementasi Zn ternyata TKE, TKP, TKZn, dan kejadian infeksi secara bersama-sama juga mempengaruhi perubahan skor Z TB/U sebesar 23,2\%, namun hanya TKZn yang berpengaruh signifikan terhadap perubahan skor Z TB/U. Hal ini disebabkan karena $\mathrm{Zn}$ dalam mempengaruhi pertumbuhan bukan hanya diperoleh dari suplementasi tetapi juga dari asupan makanan yang mengandung $\mathrm{Zn}$.

\section{SIMPULAN DAN SARAN}

Suplementasi $\mathrm{Zn}$ berpengaruh terhadap perubahan skor $\mathrm{Z} \mathrm{TB} / \mathrm{U}$, asupan gizi (TKE, TKP, TKZn), dan kejadian infeksi. Perubahan skor Z TB/U lebih tinggi pada kelompok perlakuan dibanding kelompok pembanding. Terjadi peningkatan rerata TKE, TKP, dan TKZn pada kelompok perlakuan daripada kelompok pembanding. Lama dan frekuensi diare, batuk, pilek, dan demam lebih singkat pada kelompok perlakuan dibanding kelompok pembanding. Selain suplementaasi $\mathrm{Zn}$, faktor yang mempengaruhi perubahaan skor Z TB/U adalah TKZn.

Berdasarkan hasil penelitian direkomendasikan bahwa pemberian suplemen $\mathrm{Zn}$ perlu dipertimbangkan dalam program penanganan masalah gizi terutama terjadinya stunting pada anak.

\section{DAFTAR PUSTAKA}

1. Supariasa IDN, Bakri B, Fajar I. Penilaian Status Gizi. EGC, Jakarta;2002:38-62.

2. Siregar R., Lilisianawati, Lestari ED, Salimo H. 2011. Effect of zinc suplementation on morbidity among stunted children in Indonesia. Paediatr Indones. 2011;51:128-132.

3. Riset Kesehatan Dasar (Riskesdas) 2010. Laporan Hasil Riset Kesehatan Dasar (Riskesdas) 2010. Badan Litbangkes, Depkes RI, Jakarta, 2010.

4. Riset Kesehatan Dasar (Riskesdas) 2007. Laporan Jawa Tengah. Badan Litbangkes, Depkes RI, Jakarta, 2007.

5. Brown KH, Peerson JM, Rivera J, Allen LH. Effect of supplemental zinc on the growth and serum zinc concentrations of prepubertal children: a meta-analysis of randomized controlled trials. Am J Clin Nutr. 2002;75:1062-71.
6. Shankar AH, Prasad AS. Zinc and immune function: the biological basis of altered resistance to infection. Am J Clin Nutr. 1998;68(Suppl.2):S447-63.

7. Herman S. Rancangan studi (Desain) Penelitian Kesehatan. Makalah disampaikan pada Pelatihan Metode Penelitian, Dinas Kesehatan Kalimantan Selatan, Banjarmasin, 2006.

8. Dijkhuizen MA. Concurrent Micronutrient Deficiencies in Lactating and Their Infants in Indonesia [dissertation]. University of Wageningen, the netherlans;2001.

9. Purwaningsih E. Pengaruh suplementasi seng dan besi terhadap pertumbuhan, perkembangan psikomotorik dan kognitif bayi : uji lapangan di Indramayu, Jawa Barat. Tesis pada Universitas Indonesia Jakarta: 2001.

10. Satoto. Zinc Deficiency among Indonesian Children. In : Joint symposium between Department of Nutrition \& Department Paediatrics Faculty of Medicine, Sebelas Maret University and the Center for human Nutrition, University of Shiffiels, UK ; Surakarta;2001.

11. Herman S. Rapid Nutrition Assessment in Disaster Affected Districts in Nangroe Aceh Darussalam (NAD). Makalah disampaikan pada Sosialisasi Adopsi Standard Makanan Bayi pada Keadaan Darurat, Bogor:2005.

12. Brown KH. Commentary : Zinc and child growth. Int J Epidemiol. 2003;32 (6):1103-1104.

13. King JC. Zinc : an essential but elusive nutrient. Am J Clin Nutr. 2011;94 (suppl):679S-84S.

14. Hidayat A. Seng (zinc) : esensial bagi kesehatan. Bagian Ilmu Kesehatan Masyarakat Fakultas Kedokteran Universitas Trisakti. J Kedokter Trisakti 1999;18(1):19-26.

15. Ninh NX, Thissen JP, Collette L, Gerard G, Khoi $\mathrm{HH}$, Ketelslegers JM. Zinc supplementation increases growth and circulating insulin like growth factor I (IGF-I) in growth-retarded Vietnamese children. Am J Clin Nutr. 1996;63:514-9.

16. Backeljauw P. Insulin-like growth factor I deficiency. Professor of Pediatrics. Cincinnati Children's Hospital Medical Center. University of Cincinnati College of Medicine, 2008.

17. Thu BD, Schultink W, Dillon D, Gross R, Leswara ND, Khoi HH. Effect of daily and weekly micronutrient supplementation on micronutrient deficiencies and growth in young Vietnamese children. Am J Clin Nutr. 1999;69: 80-6.

18. Muller O, M Garenne, P Reitmaier, A Baltussen van Zweeden, B Kouyate, H Becher. Effect of zinc supplementation on growth in West African children : a randomized double-blind placebo- 
controlled trial in rural Burkina Faso. Int $\mathrm{J}$ Epidemiol. 2003; 32:1098-1102.

19. Taneja S, Tor A. Strand, Halvor Sommerfelt, Raji $\mathrm{v}$ Bahl, Nita Bhandari. Zinc supplementation for four months does not affect growth in Young North Indian children. J Nutr. 2010;140:630-634.

20. Pamungkasiwi E. 2006. Mikromineral seng dalam kehidupan manusia. Dinas Kesehatan Provinsi Yogyakarta [Internet]. 2006 [diakses 12 Agustus 2012]. Available from: http://www.dinkesdiy.org.

21. Shay NF, Manigian HF. Neurobiology of zincinfluenced eating behavior. J Nutr. 2000;130 (suppl): 1493S-9S.

22. Golden MNH.. Childhood Malnutrition : Its Consequences and Management. Spesific Deficiencies Versus Growth Failure : Type I and Type II Nutrients. Joint Symposium between Department of Nutrition \& Department of Paediatrics Faculty of Medicine, Sebelas Maret University and The Centre for Human Nutrition. University of Sheffield, UK. Surakarta, Indonesia, 2001.

23. Bhutta AZ, Sazawal S, Hidayat A. Therapeutic effects of oral zinc in acute and persistent diarrhea in children in developing countries: pooled analysis of randomizol controlled trials. Am J clin Nutr. 2000;72:1516-22.

24. Artana WD, Suraatmaja S, Aryasa KN, Suandi IKG. Peran suplementasi mineral mikro seng terhadap kesembuhan diare. Sari Pediatri 2005;7(1):15-18.

25. Umeta M. 2003. Role of Zinc in Stunting of Infants and Children in Rural Ethiopia [thesis]. Division of Human Nutrition and Epidemiology, Wageningen University, The Netherlands:2003.

26. Siregar CD. Pengaruh infeksi cacing usus yang ditularkan melalui tanah pada pertumbuhan fisik anak usia sekolah dasar. Sari Pediatr. 2006;8:1127. 